Original Research

\title{
Physicochemical Properties and Total Coliform Distribution of Selected Rivers in Osun State, Southwestern Nigeria
}

\author{
Yinka Titilawo ${ }^{1,2 *}$, Aderonke Akintokun ${ }^{3}$, Olufunke Shittu ${ }^{3}$, \\ Mobolaji Adeniyi ${ }^{4}$, Janet Olaitan ${ }^{4}$, Anthony Okoh ${ }^{1}$ \\ ${ }^{1}$ SAMRC Microbial Water Quality Monitoring Centre, University of Fort Hare, Alice, South Africa \\ ${ }^{2}$ Department of Biology/Microbiology/Biotechnology, Federal University, Ndufu-Alike, Ikwo, Ebonyi State, Nigeria \\ ${ }^{3}$ Department of Microbiology, Federal University of Agriculture, Abeokuta, Nigeria \\ ${ }^{4}$ Department of Biological Sciences, Osun State University, Osogbo, Nigeria
}

Received: 17 November 2017

Accepted: 23 December 2017

\begin{abstract}
Rivers are important freshwater resources for domestic and industrial activities, and the availability of good-quality freshwater is indispensable for preventing water-borne diseases and improving quality of life, especially in communities that lack a water supply system. The physicochemical parameters and coliform distribution of some selected rivers in Osun State, soutwestern Nigeria were evaluated using standard analytical procedures. The physicochemical qualities ranged as follows: $\mathrm{pH}$ (6.9-7.6), temperature $\left(26-29^{\circ} \mathrm{C}\right)$, turbidity $(2.28=9.46 \mathrm{NTU})$, electrical conductivity $(229-581 \mu \mathrm{S} / \mathrm{cm})$, nitrate (0.03-0.05 mg/L), nitrite (0.00-0.01 mg/L), sulphate (3.33-20.33 mg/L), chloride ions (7.83-27.33 mg/L), dissolved oxygen (4.23-5.57 mg/L), total dissolved solids $(56-184 \mathrm{mg} / \mathrm{L})$, total hardness $(78-519 \mathrm{mg} / \mathrm{L})$ and alkalinity $(50.67-146.67 \mathrm{mg} / \mathrm{L})$. Total coliforms were detected in counts ranging from 59 to $176 \mathrm{CFU} / 100 \mathrm{ml}$ of water sample. One-way ANOVA showed that $\mathrm{pH}$, temperature, electrical conductivities, nitrates, nitrites, chloride, dissolved oxygen, total dissolved solid, total hardness and alkalinity were significantly different $(P<0.05)$, whereas turbidity and sulphate were not significantly different $(\mathrm{P}>0.05)$ from each parameter with respect to sampling sites. Generally, results from this study suggest that the river waters are not suitable for consumption, domestic or recreational use, and confirm the importance of protecting the freshwater resources of southwestern Nigeria.
\end{abstract}

Keywords: rivers, water quality, physicochemical parameters, coliforms, pollution, Nigeria

*e-mail: olayinkatemi@yahoo.co.uk 


\section{Introduction}

Rivers are important sources of natural waters for domestic and industrial activities, and the availability of good quality water is indispensable for preventing water-borne diseases and improving quality of life [1]. They are important multi-usage resources, including sources of drinking water, irrigation, aquaculture and energy production [2]. They are self-sustaining and vital ecosystems that are capable of supporting plant and animal lives indefinitely if left undisturbed [3]. Water is required by all living things for cellular metabolism. Activities such as domestic, agriculture, industry, transportation and recreation, upon which the continuous existence of human life on this planet relies, require water of good quality [4].

Globally, most rural dwellers largely cater their need for waters from rivers, dams, springs or shallowdug wells [5-6], with a concomitant increase in pollution from agriculture, mining, urbanization and industrialization sources rendering the available water resources useless and hazardous to consumer health [7]. In recent years, both the anthropogenic influences and natural processes rendering water bodies unsuitable for both primary and secondary uses have increased exploitation of water resources [8-9].

Water intended for human consumption should be safe, healthy, easily accessible, adequate in quantity, readily available and free from contamination [10]. Although access to water has been internationally recognized as a fundamental human right [11], owing to its essentiality in human wellbeing and life's sustenance, nonetheless, it has also long been suspected of being responsible for many human illnesses. Water quality is described by its physical, chemical and microbiological characteristics [12]. Microbiological examination of river waters is obligatory for use-related purposes such as drinking water production, irrigation and recreation [13]. Water quality is at present a global issue, especially when considering its implications to humanity in terms of water-borne diseases. Its deterioration as a result of pollution and contamination of ground and surface waters has led to the disturbance of ecosystem balance. Water quality can be presented as a set of inter-related parameters $(\mathrm{pH}$, oxygen concentration, temperature, etc.) which affect the functioning of aquatic biota [14].

About 1.6 billion children under the age of 5 die annually due to unsafe drinking water, coupled with a lack of basic sanitation. About 1.1 billion people in the world lack basic access to clean, safe and adequate water resources and $85 \%$ of them live in rural areas, with approximately $80 \%$ of illnesses and deaths in developing countries due to the use of water of poor quality [1516]. Investigations of hygiene, sanitation and universal access to safe drinking water supplies have proven to be an essential step in reducing and/or controlling the preventable associated water-borne diseases [17].

Unfortunately, in many countries around the world, including Nigeria, drinking water supply systems have become increasingly compromised by pollution. As a result of inadequate treatment and disposal of waste from human activities, industrial discharges, contaminants such as bacteria, viruses, heavy metals, nitrates and salts have found their ways into water supplies [18]. Nigeria, despite being the largest African country and the continent's biggest oil exporter, has been characterized by low levels of access to an improved water source with its coverage rates being among the lowest in the world. Access to improved water supply in Nigeria was $47 \%$ in 1990 , with $79 \%$ (27 million) of the urban population of 34 million having access, compared to $30 \%$ (19 million) of the 63 million people living in rural areas. By 2008 the percentage of the population with access had increased to $58 \%$ (86 million), spread across $75 \%$ of the urban population and $42 \%$ of the rural population [17].

Due to the inability of governments to meet the ever-increasing water demand, some communities resort to surface water sources as alternatives sources of drinking water, and Osun State is not exempted from this development. Available data from Targets of the State Water and Sanitation Projects reveal that access to clean water in rural and urban areas is still far from being met. Hence, in this paper we report on the physicochemical and microbiological qualities of some typical rivers in Osun State, Nigeria in view of the increasing dependence by the populace on the rivers for their daily water needs.

\section{Materials and Methods}

\section{Description of the Study Areas}

Osun State is located in southwestern Nigeria. It covers an area of approximately $10,456 \mathrm{~km}^{2}$ and borders Ogun, Kwara, Oyo and Ondo states. Osun, with co-ordinate $7^{\circ} 30^{\prime} \mathrm{N} 4^{\circ} 30^{\prime \prime} \mathrm{E}$, is nicknamed state of the living spring. It is an inland state with a population of 3, 999,800 [19]. The main sources of water supply in the state are by impounding rivers and construction of dams on the major rivers in the state, with the state water scheme accounting for about 39\% of the total design capacity and actual production level of all the water schemes in the state. Consequently, communities have resorted to depending on the surrounding rivers for their daily needs [20]. Table 1 below shows the morphometric details of the sampling sites and their geographic co-ordinates.

\section{Sample Collection and Processing}

Triplicate water samples were collected from 10 different rivers in the state over a period of 3 months (March to May, 2016). The samples were collected in the morning using sterile $5 \mathrm{~L}$ plastic containers. Sampling was done by dipping sterile sample bottles at approximately $20-30 \mathrm{~cm}$ below the surface of the water, 
after which they were transported in cooler boxes to the laboratory for analysis within $6 \mathrm{~h}$ of collection using the recommended procedure [21].

\section{Determining Physicochemical Parameters}

The $\mathrm{pH}$ of the samples was determined using a Jenway pH meter (3310 model) already standardized by using standard analytical grade buffer solutions of $\mathrm{pH}$ 4.0, 7.0 and 10 values before analyses. Temperature was determined using a calibrated mercury thermometer (Jenway 3015 model) at the sampling sites by suspending a thermometer about $10 \mathrm{~cm}$ below the surface of water for at least 2 minutes before taking the reading [22]. A turbidimeter was used to measure turbidity of the water samples while electrical conductivity and total dissolved

Table 1. Morphometric details of the sampling sites.

\begin{tabular}{|c|c|c|c|}
\hline $\begin{array}{l}\text { Sampling } \\
\text { site }\end{array}$ & Site name & Description & Coordinates \\
\hline R1 & Erinle-Ede & $\begin{array}{l}\text { The River Erinle which rises just South of Offa. Its elevation is } 269 \mathrm{~m} \text { and has residential, } \\
\text { commercial and industrial areas. The old and new dams on the river supply water to the neigh- } \\
\text { bouring settlements including Osogbo, the state capital. }\end{array}$ & $\begin{array}{l}7^{\circ} 44^{\prime} 44^{\prime \prime N} \\
4^{\circ} 29^{\prime} 22^{\prime \prime} \mathrm{E}\end{array}$ \\
\hline $\mathrm{R} 2$ & Ido Osun & $\begin{array}{l}\text { The River Ido Osun has an elevation of } 270 \mathrm{~m} \text {, takes its source from the Erinle river, asides } \\
\text { being the closest. Activities sighted along the river courses include animal rearing, fishing, ir- } \\
\text { rigation domestic and recreations. }\end{array}$ & $\begin{array}{c}7^{\circ} 49^{\prime} 01 " \mathrm{~N} \\
4^{\circ} 26^{\prime} 41^{\prime \prime} \mathrm{E}\end{array}$ \\
\hline $\mathrm{R} 3$ & $\begin{array}{l}\text { Osun- } \\
\text { Osogbo }\end{array}$ & $\begin{array}{l}\text { The River Osun has an elevation of } 320 \mathrm{~m} \text {. Its drainage system rises in Oke-Imesi ridge, about } \\
5 \mathrm{~km} \text { north of Efon-Alaiye, Ekiti state of Nigeria, and flows north through the Itawure before } \\
\text { winding its way Westwards through Osogbo and Ede and southwards to lower course where it } \\
\text { empties into Lekki lagoon in Lagos state and the Atlantic Gulf of Guinea. Its global popularity } \\
\text { lies in its sacredness as a national and international tourist center and worship shrine. Agricul- } \\
\text { tural activities such as farming and fishing take place along the river courses. }\end{array}$ & $\begin{array}{c}7^{\circ} 46^{\prime} 04^{\prime \prime N} \\
4^{\circ} 34^{\prime} 00^{\prime} \mathrm{E}\end{array}$ \\
\hline $\mathrm{R} 4$ & Oba-Iwo & $\begin{array}{l}\text { The River Oba has an elevation of } 226 \mathrm{~m} \text {. It is located in Iwo township, the most populous } \\
\text { Local Government in the State and with a density of } 245 \mathrm{sq} \mathrm{km} \text { and a population of } 191,348 \text {. } \\
\text { The town is reliant on the river for its domestic and agricultural activities. }\end{array}$ & $\begin{array}{c}7^{\circ} 38^{\prime} 01 " \mathrm{~N} \\
4^{\circ} 11^{\prime} 20^{\prime \prime} \mathrm{E}\end{array}$ \\
\hline R5 & Ejigbo & $\begin{array}{l}\text { The River Ejigbo has an elevation of } 354 \mathrm{~m} \text {. The characteristic heavy annual rainfall in the area } \\
\text { greatly supports the development of thick forest and the production of food and cash crops and } \\
\text { varieties of fruits. Waters used by women for the processing of palm oils are sourced from the } \\
\text { river and the availability of the river has been the strong pillar behind the large-scale fishing } \\
\text { and fishing business in the zone. In } 2008 \text {, Ejigbo was ranked highest producer of life cat fish } \\
\text { in Osun State. }\end{array}$ & $\begin{array}{l}7^{\circ} 54^{\prime} 0^{\prime \prime} \mathrm{N} \\
4^{\circ} 18^{\prime} 54^{\prime \prime} \mathrm{E}\end{array}$ \\
\hline R6 & $\begin{array}{l}\text { Ilobu- } \\
\text { Okinni }\end{array}$ & $\begin{array}{l}\text { The River Ilobuis watered by Ojutu River, Erinle River, Konda River and a few other streams. } \\
\text { It is located in a sparsely forested area and bounded in the north by Ifon-Osun, south by Os- } \\
\text { ogbo, east by Oba and west by Erin-Osun. Its elevation above sea level is } 301 \mathrm{~m} \text {. Farming } \\
\text { and animal rearing are linked to presence of the river in the zone. Many ugly and undesirable } \\
\text { practices such as car washing, swimming and bathing by farmers and bricklayers take place } \\
\text { within and around the river. }\end{array}$ & $\begin{array}{c}7^{\circ} 50^{\prime} 06 " \mathrm{~N} \\
4^{\circ} 29^{\prime} 14^{\prime \prime} \mathrm{E}\end{array}$ \\
\hline R7 & $\begin{array}{l}\text { Asejire- } \\
\text { Ikire }\end{array}$ & $\begin{array}{l}\text { The River Asejirehas an elevation of } 146 \mathrm{~m} \text {. Its availability has been the major factor behind } \\
\text { the fine and conducive climate and cultivation of arable and cash crops. The typical luxuriant } \\
\text { evergreen rainforest vegetation cover during the raining season also supports rearing of cattle } \\
\text { and other domestic animals, large scale fishing and fishing business. The location of the Nige- } \\
\text { rian Bottling Company (Coca Cola) in the area has been linked to the river. The river equally } \\
\text { serves as the geographical boundary between Osun and Oyo states. }\end{array}$ & $\begin{array}{c}7^{\circ} 25^{\prime} 44^{\prime \prime N} \\
4^{\circ} 13^{\prime} 14^{\prime \prime} \mathrm{E}\end{array}$ \\
\hline R8 & Shasha & $\begin{array}{l}\text { The River Shasha has an elevation of } 208 \mathrm{~m} \text {, located in Edun Abon in Ife North Local Govern- } \\
\text { ment Area of the state, a settlement inhabited by the Igbo people whose origin are traced to } \\
\text { the Eastern and Southeastern parts of Nigeria. The river is believed to be friendly to all in that, } \\
\text { it is harmless, does not discriminate and ever ready to proffer solutions to human problems } \\
\text { willingly and freely especially to waiting mothers who only need to collect and drink for con- } \\
\text { ception. Cultivation of food crops, animal rearing and processing of palm oils are some of the } \\
\text { activities surrounding the catchment. }\end{array}$ & $\begin{array}{c}7^{\circ} 22^{\prime} 32^{\prime \prime N} \\
4^{\circ} 28^{\prime} 11^{\prime \prime} \mathrm{E}\end{array}$ \\
\hline R9 & Ila-OkeIla & $\begin{array}{l}\text { The River Ila/Oke Ila has an elevation of } 550 \mathrm{~m} \text {. The availability of the river has greatly } \\
\text { enhanced the large scale cultivation of palm tree plantation which in turns support the com- } \\
\text { mon traditional profession of the indigenes of the town, palm-wine tapping. }\end{array}$ & $\begin{array}{c}8^{\circ} 01^{\prime} 50^{\prime \prime} \mathrm{N} \\
4^{\circ} 59^{\prime} 03^{\prime \prime} \mathrm{E}\end{array}$ \\
\hline $\mathrm{R} 10$ & $\begin{array}{l}\text { Inisha- } \\
\text { Okuku }\end{array}$ & $\begin{array}{l}\text { The River Inisha/Okuku has an elevation of } 352 \mathrm{~m} \text { above sea level. The river is } 36 \mathrm{~km} \text { long } \\
\text { and on it was impounded a reservoir with a large capacity designed to supply potable wa- } \\
\text { ter to the neighbouring communities. Other benefits derived from the rivers are fishing, } \\
\text { irrigation and domestic activities. }\end{array}$ & $\begin{array}{r}8^{\circ} 01.32^{\prime \prime N} \\
4^{\circ} 42^{\prime} 11 " \mathrm{E}\end{array}$ \\
\hline
\end{tabular}


solids were determined by using a $\mathrm{HACH}$ conductivity meter (4510 model). Dissolved oxygen content of the samples was determined using a digital dissolved oxygen meter. Nitrate, nitrite and sulphate contents were determined using a calibrated V2000 multi-analyte photometer, while the concentrations of chloride, total hardness and alkalinity were determined using the standard titrimetric methods [22].

\section{Enumeration of Total Coliform Populations}

The most probable number (MPN) technique was employed for total coliforms. This was achieved using multiple $5 \times 5$ tube regimen with MacConkey broth as the cultivation medium [23]. The bottles were incubated and observed at the end of 24 and 48 hours for presumptive and confirmatory tests, respectively. The numbers of positive bottles indicated by colour change and gas formation were recorded and counts estimated from the MacCrady interpretative chart. The MPN of the coliform populations was expressed as $\mathrm{CFU} / 100 \mathrm{ml}$.

\section{Statistical Analysis}

Statistical analysis was performed using IBM Statistical Package for Social Sciences [(SPSS) Version 20 software]. Data obtained in this study were subjected to descriptive statistical analysis $(95 \%$ confidence interval). One-way analysis of variance (ANOVA) was done to test differences among the parameters measured with respect to sampling locations. Statistical significance was set at $P$ values $<0.05$. Correlation between the physico-chemical properties and total coliforms was observed using a 2-tailed Pearson's correlation analysis. Correlations and test of significance were considered statistically significant when $P$ values were $<0.05$ and 0.01 .

\section{Results and Discussion}

Table 2 shows the results of the physicochemical parameters analyzed together with the WHO standards and statistical $P$ values, while Fig. 1 shows the mean values obtained for total coliform counts of the river water samples. $\mathrm{pH}$ measures the intensity of acidity and alkalinity of water. In the present study, the $\mathrm{pH}$ obtained in all the sites ranged from 6.9 to 7.6 and fell within the WHO recommended limits of 6.5-8 for drinking water [10]. While the lowest $\mathrm{pH}$ was obtained at $\mathrm{R} 3$, the highest was at $\mathrm{R} 9$. The $\mathrm{pH}$ regimes in this study showed significant difference in all 10 sampling sites $(P<0.05)$ (Table 2). Generally, most of the water samples are alkaline and this is in agreement with reports from similar studies [24-25]. Changes in $\mathrm{pH}$ can be caused by photosynthesis, respiration, air temperature, disposal of industrial wastes, geology and mineral content of the catchment area, acid mine drainage, agricultural runoff, carbon dioxide concentration in the atmosphere, and

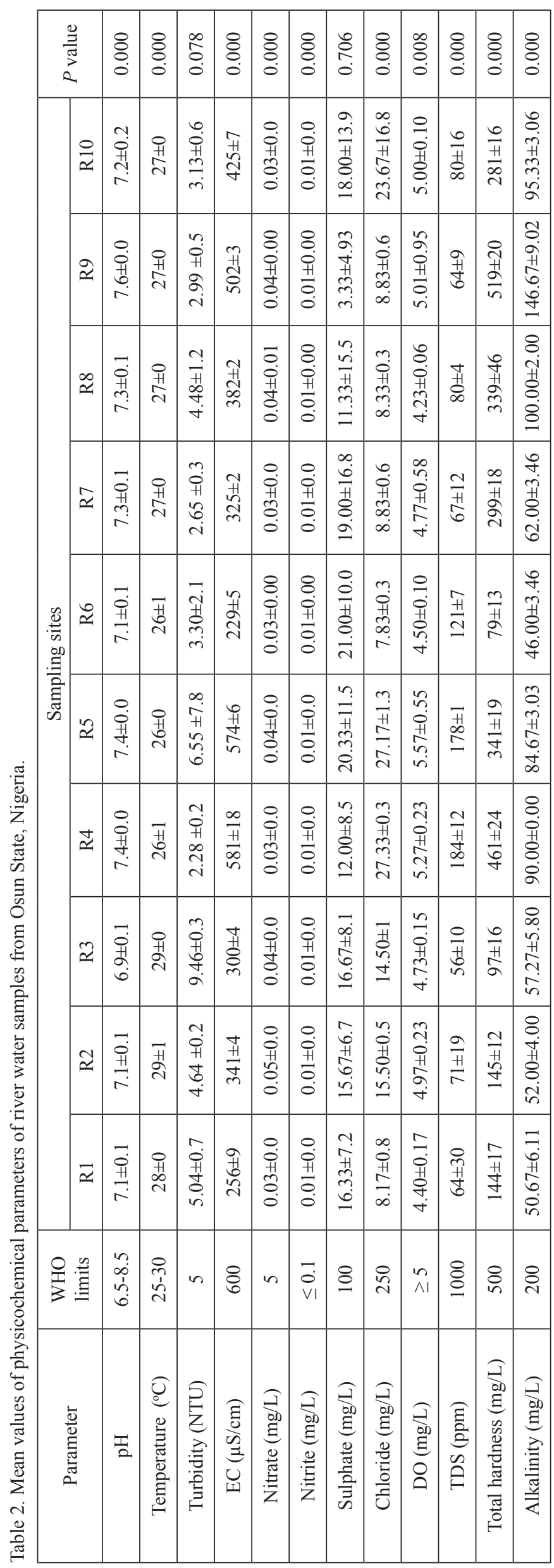




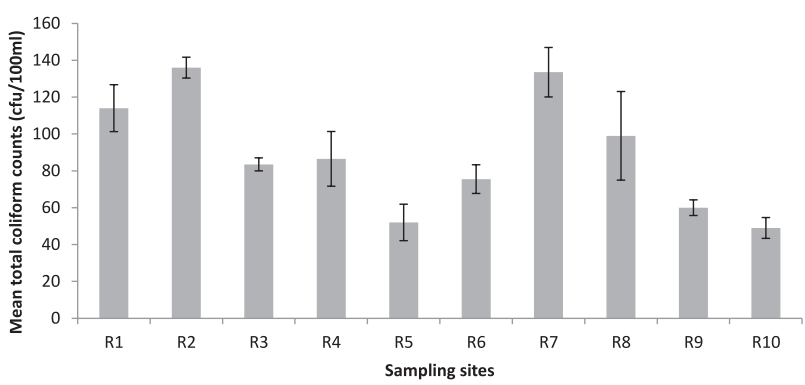

Fig. 1. Mean values of total coliform counts obtained for each sampling location.

accumulation and decomposition of organic detritus in the water producing weak carbonic acids that impact $\mathrm{pH}$ [26].

Water temperature is an important factor that influences the rate of all biological activities. It can therefore be used as a first step in predicting the effects of human activities on aquatic lives [27]. The mean temperature values obtained in this study ranged $26-29^{\circ} \mathrm{C}$. The maximum surface water temperature was observed at R3, whereas the minimum was at R6. There was a significant difference in the temperature regimes by sampling sites $(P<0.05)$ (Table 2$)$. Most of the sites are covered by thick forests whose upper canopies prevent sunlight penetration, cast shadow upon the water surfaces and thereby cool the waters. Temperature generally drives the chemical reactions in an aquatic system and warmer temperatures $\left(>25^{\circ} \mathrm{C}\right)$ may influence the toxicity of some substances, like ionized ammonia that may be found dissolved in water [28]. However, in this study, the temperature regimes in all the sampling sites were within the acceptable limit $\left(25-30^{\circ} \mathrm{C}\right)$ for domestic water uses.

Turbidity of water is the expression of optical property in which the light is scattered by the particles present in the water [29]. It is an indication of suspended materials in river water. High turbidity values indicate the possible presence of micro-organisms, clays, silts and other suspended solids in water, which affect its aesthetic value by causing it to appear turbid [30]. The mean turbidity values of the river water samples ranged from 2.28 to 9.46 NTU. The highest value was recorded at R3 and the lowest at R4. Sampling sites R1, R3 and R5 turbidities exceeded the WHO acceptable limit of $5 \mathrm{NTU}$, while others fell within acceptable limits. The high values of turbidities have been previously reported [31]. These results did not show any significant difference at the $95 \%$ confidence limit in the sampling locations (Table 2). An increase in turbidity is observed when the colour of the water changes from white to light-yellowish, reddish or grayish. Highly turbid water has an altered odour and taste, and its visual properties are negatively impacted and, where necessary, will significantly increase water treatment costs due to the amount of flocculants needed to clarify the water [32]. Light penetration is also highly affected by turbidity, and higher levels of turbidity strongly associate with higher levels of pathogenic microorganisms such as bacteria, viruses and parasites. Thus the occurrence of higher indicator bacterial numbers in any water sample could be linked to the higher turbidity levels [33]. Suspended silt and clay, organic matter, and plankton can contribute to turbidity; hence, turbidity in a stream will fluctuate before, during and after turbulent flow [34-35].

Electrical conductivity (EC) estimates the amount of total dissolved salts, or the total amount of dissolved ions in the water and is controlled by, among other factors; the function of the geology of the catchment area that determines the chemistry of the watershed soil and ultimately the water [36]. The overall conductivity obtained in this study ranged from 229 to $581 \mu \mathrm{S} / \mathrm{cm}$ and fell within the WHO maximum permissible limits $(600$ $\mu \mathrm{s} / \mathrm{cm}$ ) for drinking water. A significant difference was observed to EC values in all the sampling sites $(\mathrm{P}<0.05)$ (Table 2). With respect to EC, the results obtained in this study suggest that the river waters could be fit for domestic use. The low EC values observed in all the sampling points could indicate the presence of a low amount of dissolved inorganic substances in the samples [37]. Previous findings indicate that sewage disposal tends to increase the EC levels of the receiving water body because of the high concentrations of salts and ions in the sewage [38]. Sewage disposal and urban surface run-off from agricultural lands and roads contribute to the increase in conductivity. Similar findings have been observed elsewhere [1, 35-36]. High EC level indicates the presence of a high amount of dissolved inorganic substances in ionized form and can be disastrous to aquatic life because of increased salinity in the stream and possible smothering of the stream bottom, especially if the stream is deep [37].

Nitrates indicate the presence of fully oxidized organic matter. The mean nitrate values obtained in the river water samples were lower than the WHO permissible limits for drinking water. Nitrates however were noted in low concentrations within the range of 0.03 and $0.05 \mathrm{mg} / \mathrm{l}$ water and fell within the WHO water quality target of $5.0 \mathrm{mg} / \mathrm{L}$ [39]. This implies that analysed water samples contained low level of oxidized organic matter. There was a significantly higher difference $(\mathrm{P}<0.05)$ of nitrates at all sampling sites (Table 2). With regards to the extremely low values obtained for nitrate, the waters could be suitable for sundry purposes. Nitrates themselves are relatively non-toxic and normal individuals have low levels $(0.5-2 \%)$ of methaemoglobin in their blood [40]. When in excess, they may result in eutrophication, which leads to loss of diversity in the aquatic biota and overall ecosystem degradation through algal blooms, excessive plant growth, oxygen depletion and reduced sunlight penetration [41]. Levels above permissible limit are considered harmful to aquatic lives [42]. Excess levels of nitrates (above $10 \mathrm{mg} / \mathrm{L}$ ) cause methemoglobinemia; a blue baby syndrome in which blood loses its ability 
to carry sufficient oxygen [39]. Although nitrates levels that affect infants do not pose a direct threat to older children and adults, they do indicate the possible presence of other more serious residential or agricultural contaminants such as bacteria or pesticides [43].

Approximately, nitrite levels complied with the acceptable limit $(0.5 \mathrm{mg} / \mathrm{L})$ during the study as the same concentration was recorded. Nitrite concentrations were significantly different at all the sampling sites $(\mathrm{P}<0.05)$ (Table 2). This indicates that most of the rivers receive very low amounts of organic materials. The low concentrations of nitrite obtained in this study depict low anthropogenic activities. However, nitrite easily changes to nitrate as the end product of the oxidation of organic nitrogen and ammonia, and may therefore be unable to pose a health risk in the case of people using the raw water since the detected nitrate levels were within the safety guidelines set for water intended for human consumption. Nitrites could be toxic at certain concentrations and cause damage to gills as well as diffusing into red blood cells, resulting in the formation of methhaemoglobin; which lacks the ability to bind with oxygen and thereby resulting in stunted oxygen transport. A high nitrite level is considered to pose health threats to communities when the receiving water bodies are used for domestic purposes [44].

Sulphates are formed due to the decomposition of various sulphur-containing substances present in water bodies. The sulphate ions $\left(\mathrm{SO}_{4}^{2-}\right)$ occur naturally in most water supplies and hence are present in natural water bodies. The mean values obtained for the sampling locations were found between the range of 3.33 and $20.33 \mathrm{mg} / \mathrm{L}$. The results revealed that sulphate concentrations in the river waters did not differ significantly in the sampling sites $(P>0.05)$ (Table 2). The concentrations obtained in this study are low compared to the WHO permissible limit of $250 \mathrm{mg} / \mathrm{L}$, which could be an indication that sulphate easily precipitates and settles to the bottom sediment of the river and is derived from discharge of domestic sewage, surface runoff and agricultural activity brought into the rivers [45].

Generally, nutrients are naturally present in the environment and their cycling processes prevent the accumulation of very high concentrations of nutrients. However, human activities have increased environmental nitrate and nitrite concentrations, with agriculture being the major source. This includes increased use of nitrogen-containing fertilizers as well as concentrated livestock and poultry farming; the latter two produce millions of tons of nitrate-containing manure each. Nitrate and nitrite compounds are highly soluble in water and quite mobile in the environment year. They have a high potential for entering surface water during rainfall events, as nitrates in applied fertilizers can be dissolved in runoff that flows into streams [10, 40, 46]. Sulphur is an important building block of proteins and many other organic compounds. Within water, it occurs mostly as sulphate ion, though non-toxic, but its excess forms sulphuric acid $\left(\mathrm{H}_{2} \mathrm{SO}_{4}\right)$, which has a devastating effect upon aquatic ecosystems, and also diarrhoea can be caused due to a higher amount of sulphate in drinking water. Sulfate causes scaling in industrial water supplies and odour and corrosion in wastewater treatment processes due to its reduction to $\mathrm{H}_{2} \mathrm{~S}$. Its main source is industrial discharge that contains sulfate salts and domestic wastes [47].

Chloride is an important anion used for determining total salinity of water and serves as an indicator of pollution by sewage or some industrial wastes or intrusion of seawater or other saline waters [47]. In the present work, chloride concentrations ranged from 7.83 to $27.33 \mathrm{mg} / \mathrm{L}$, and were within the allowance of the $250 \mathrm{mg} / \mathrm{L}$ set limit. Chloride concentrations recorded at all sampling locations were significantly different $(P<0.05)$ (Table 2). People habituated to higher chloride in water, which can bring laxative effects. Chloride in fresh water is released through human urine and faeces, and the disposal of sewage and industrial wastes [48]. The presence of chlorides in natural waters is due to the leaching of chloride-containing rocks and soils with which the water comes in contact. Chlorides are the most stable components in water and its concentration is largely unaffected by most natural physicochemical and biochemical processes. Hence the value of its concentration in water is a useful measure in water samples [24].

Dissolved oxygen (DO) is a fundamental factor for metabolism of the aerobic aquatic organisms, and it is important in determining the natural self-purification capacity or freshness of a river [49-50]. In this study, the dissolved oxygen (DO) content varied in a range of 4.23 to $5.57 \mathrm{mg} / \mathrm{L}$. (Table 2). Sampling sites R4, R5, R9 and R10 concentrations exceeded the acceptable limit of $\geq 5 \mathrm{mg} / \mathrm{L}$, while those of other sites fell within. Measurement of dissolved oxygen is a primary parameter in all pollution studies. The quantity of DO in streams is dependent on the water temperature, the amount of sediment, level of oxygen taken out of the system by respiring and decaying organisms, and the amount of oxygen restored back into the system by plants' photosynthesis, stream flow and aeration [5152]. The results imply that some of the rivers in Osun are clean with respect to organic pollution [53-54]. The high temperature, addition of sewage and other waste might be responsible for low values of DO in some sites. Good levels of DO in all the sampling sites of the river may also be indicative of high re-aeration rates and rapid aerobic oxidation of biological substances [38]. The depletion of dissolve oxygen in water is due to high temperatures and increased microbial activity [55]. The threshold limit for DO is $5.0 \mathrm{mg} / \mathrm{L}$ in drinking water and should be greater than $5.0 \mathrm{mg} / \mathrm{L}$ in water to be used for agricultural purposes [56]. Although there is no health guideline for DO content in water, low concentration in water supplies may encourage microbial reduction of nitrate to nitrite and sulphate to sulphite, and can also cause an increased ferrous iron 
concentration in solution with subsequent discolouration at the tap point [57]. Low DO concentrations (below $70 \%$ saturation) may result in anaerobic conditions and cause bad odour in water and when combined with the presence of toxic substances, leading to stress responses in aquatic ecosystems because the toxicity of certain elements such as zinc, lead and copper (not included in this study) is increased by low concentrations of DO [33, 58]. Low concentrations of DO, associated with high water temperature, also increase the adverse effects on biota [26].

Another evidence of pollution is the high level of total dissolved solid (TDS), which indicates materials carried in suspended form, and waters with high TDS are potentially unhealthy [59]. TDS levels ranged from 56 to $184 \mathrm{ppm}$ and were statistically significant across the sampling sites $(P<0.05)$ (Table 2$)$. WHO has suggested a guideline value of $500 \mathrm{ppm}$ of (TDS) for drinking water. TDS values for this study fell within stipulated guidelines [57]. A low level of TDS shows good quality of river waters, whereas very high TDS confirms the observed high conductivity value of the drinking water samples. Increased content of TDS elevates the density of water and such a medium increase in osmoregulation. As this parameter indicates, these rivers are suitable for domestic and agricultural purposes. This finding strongly agrees with the reports of other researchers [58]. Water containing more than $1000 \mathrm{pm}$ of TDS is not considered palatable for drinking, but in inevitable cases $1500 \mathrm{ppm}$ is also allowed [60]. TDS is the sum total of all of the dissolved substances in a given water body and includes hardness, alkalinity, chlorides, bromides, sulphates, silicates and all manner of organic compounds. Although elevated TDS concentration may not mean that the water is hazardous to health, it does mean the water may have aesthetic hitches or cause nuisance problems. These problems may be associated with staining or precipitation. With respect to trace metals, elevated TDS may suggest that toxic metals may be present at an elevated level [58].

Water hardness impacts water surface tension. Hard water requires a considerable amount of soap to form lather. Hardness of water is not a specific constituent but a variable and complex mixture of cations and anions [61]. It mainly depends on the amount of calcium or magnesium salts or both. In the present study, the overall mean value for total hardness ranged from 78 to $519 \mathrm{mg} / \mathrm{L}$, and was significantly different by sampling sites $(P<0.05)$. Aside from site R9, whose concentrations exceeded the specification limit of $500 \mathrm{mg} / \mathrm{L}$ for drinking water, others fell within (Table 2) [56], although they are sufficient enough to cause water hardness. This further explains the presence of carbonates/bicarbonates, which may cause poor lather formation and scales on boilers. The high level of calcium, magnesium, aluminum, potassium and sodium may be attributable to natural processes such as weathering of rocks, erosion, human activities like mining, quarrying, farming, calcium laden dust and leaching of rocks [62-63].
Alkalinity in natural water is due to free hydroxyl ion and hydrolysis of salts formed by weak acid and strong bases, and also due to salt-containing carbonates and bicarbonates or silicate and phosphate along with hydroxyl ion. Change in carbonates and bicarbonates also depend upon the release of $\mathrm{CO}_{2}$ through respiration [64]. Concentrations of total alkalinity for the investigated water samples ranged from 50.67 to $146.67 \mathrm{mg} / \mathrm{L}$ and were found within the prescribed limit of $200 \mathrm{mg} / \mathrm{L}$ [10]. They also ranged significantly at all the sampling sites $(P<0.05)$ (Table 2). The trend indicates the low level of carbonates and bicarbonates in the water and it concurs with what has been reported elsewhere [64]. The relatively high alkalinity $(>100 \mathrm{mg} / \mathrm{L})$ observed at sites R7 and R8 might likely be due to the presence of carbonates and bicarbonates in the water samples as they contribute to water hardness [65]. Some reported studies of surface water have found very low mean values for the water hardness parameter in Kusti, Sudan [66], in Kontagora Nigeria [67] and in Bhopal, India [68]. High alkalinity (above $500 \mathrm{mg} / \mathrm{L}$ ) is usually associated with high $\mathrm{pH}$, hardness and dissolved solids values in water [64]. It has been claimed that hardness is not considered a health concern at levels found in drinking water [10].

Coliforms are a broad class of bacteria found in the environment, including human excreta and other warmblooded animals. Their presence in water suggests the possibility of the presence of pathogens and parasites, with the associated disease symptoms such as diarrhoea, nausea, vomiting, cramps and other gastro intestinal distresses that in severe cases can be fatal [69]. The result of total coliform (TC) populations in the water samples were found to be generally high and ranged between 49.00 and 136.00 (CFU/100 ml) (Fig. 1). The modal TC counts were obtained at site R2 and the least at site R10 (Fig.. 1). Results of this study indicated that the river water sources were of poor microbiological quality. Although $\mathrm{TC}$ counts varied from site to site, sites R1, R2 and R7 seemed to be more polluted compared to others. From the figure it was evident that the river waters are highly contaminated, and also denote public health hazards. According to the WHO guidelines for drinking water quality, safe drinking water should not contain total coliforms, E. coli or any coliforms in a $100 \mathrm{ml}$ water sample [10]. In the present study, the total coliform counts obtained in all the sampling sites exceeded the set limit, which is indicative of faecal contamination. This clearly suggests that the river waters were contaminated by domestic sewage, human and animal excreta, which are objectionable for drinking purposes and also render the waters unsuitable for domestic use. The total coliform counts obtained for each sampling location are presented in Fig. 1. The occurrence of total coliforms in the studied rivers could be attributable to some major factors stated by Emmanuel et al. [70], in which leakage and discharge from septic tanks, inadequate sewage and solid waste disposal systems, inflow of domestic and industrial 


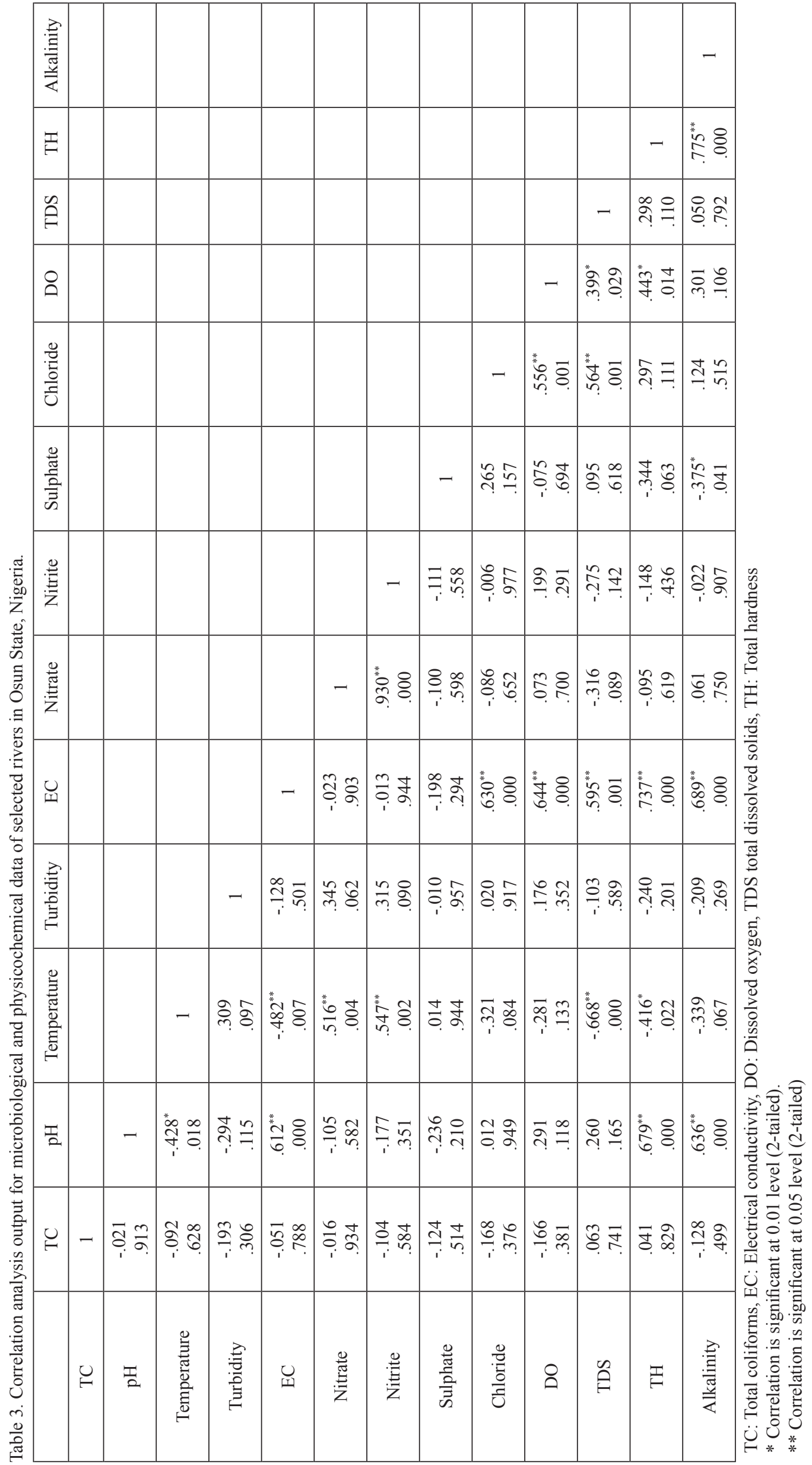


wastes, anthropogenic activities, discharges from sewage treatment plants and runoff from informal settlements are the main threats to microbiological quality of surface water. The ingestion of $E$. coli may result in haemolytic uremic syndrome, a potentially life-threatening disease similar to dysentery. E. coli and Klebsiella bacteria may also cause urinary tract infections, which primarily affect women - especially pregnant women - due to hormonal changes and physical pressure on the urinary tract [71].

A number of diseases that claim millions of lives annually in developing countries have been attributed to unsafe drinking water and inadequate sanitation measures. The quality of water, whether used for drinking, domestic, food production or recreational purposes, has implications on public health [72]. Results of the present study suggest pollution in some of the rivers, even at some points where human activities have no heavy impact on the river. A total coliform test is one of the most important biological parameters in drinking water quality. In the present study, the total coliform counts ranged from 49 to $136 \mathrm{CFU} / \mathrm{ml}$ (Fig. 1). This result is worrisome, considering the relatively high impact of population on river waters by the populace.

The correlation analysis output for both microbiological and physicochemical data of the selected rivers are performed and presented in Table 3. Some significant positive correlations were obvious. DO was positively correlated with TDS and TH at $99 \%$ confidence limit. Temperature was positively correlated with nitrate and nitrites at the $95 \%$ confidence level. Also, nitrates and nitrites were positively correlated with each other, and this is not surprising because nutrients are naturally found in the environmental waters even if they are from different sources [73]. Similarly, correlation of EC with chloride, DO, TDS, TH and alkalinity was positively significant. This finding strongly concurs with the report of Venkatesharaju et al. [3] - that EC is a dissolved salt content indicator. Other highly significant positive correlations were observed as follows: $\mathrm{pH}$ with $\mathrm{EC}, \mathrm{TH}$ and alkalinity, chloride to DO and TDS, and TH with alkalinity - all at the 95\% confidence level. Conversely, temperature was negatively correlated with EC and TDS at $95 \%$ confidence level $(r=-0.48)$ and $(r=-0.67)$ respectively. Some significant negative correlations were equally noted between $\mathrm{pH}$ and temperature, temperature and $\mathrm{TH}$, and sulphate and alkalinity at $99 \%$ confidence level. Above all, correlation study and coefficient values help in selecting treatments to minimize contaminants in surface and ground waters [3, 74].

\section{Conclusion and Recommendations}

Water of poor quality can cause disease outbreaks and contribute to background rates of disease manifesting themselves at different times of life. Striving to manage the safety of water will not only support public health, but will also promote socio- economic development and well-being. This work has examined the physicochemical properties and total coliform densities of rivers which serve as the sources of water supply to the inhabitants of the state. Although the results indicate that most of the physicochemical quality parameters of the sampled rivers fell within the acceptable limits for drinking water and, therefore, may be suitable for domestic purposes, nonetheless those few that exceeded the set limits cannot be overlooked. Similarly, the microbiological quality of the rivers suggest potential health risk if consumed. This emphasizes the need for urgent intervention in the provision of safe water supply and adequate sanitation facilities for the state dwellers. In order to maintain good water quality safe for drinking, the waters obtained from these rivers must be adequately treated by consumers. The national surveillance agency should set medium-term targets for the continuous improvement of water supplies and safeguarding of freshwater resources.

\section{Acknowledgements}

The authors are very grateful to the University of Fort Hare and the Water Research Commission of South Africa for supporting this study.

\section{Conflicts of Interest}

The authors declare no conflict of interest.

\section{References}

1. ANHWANGE B.A., AGBAJI E.B., GIMBA E.C. Impact assessment of human activities and seasonal variation on river Benue, within Makurdi Metropolis. International Journal of Science and Technology. 2, 248, 2012.

2. HACIOGLU N., BASARAN D. Monthly variation of some physicochemical and microbiological parameters in Biga Stream Biga, Canakkale, Turkey. African Journal of Biotechnology. 8, 1929, 2009.

3. VENKATESHARAJU K., RAVIKUMAR P., SOMASHEKAR R.K., PRAKASH K.L. Physicochemical and bacteriological investigation on the river Cauvery of Kollegal stretch in Karnataka. Kathmandu University Journal of Science, Engineering and Technology, 6, 50, 2010.

4. AWOMESO J.A., TAIWO A.M., GBADEBO A.M., ADENOWO J.A. Studies on the pollution of water body by textile industry effluents in Lagos, Nigeria. Journal of Applied Sciences in Environmental Sanitation. 5, 353, 2010.

5. ANECK-HAHN N.H., BORNMAN M.S., DE JAGER C. Oestrogenic activity in drinking waters from a rural area in the Waterberg District, Limpopo Province, South Africa. Water SA. 35, 245, 2009.

6. SUN Y., ASANTE F., BIRNER, R. Opportunities and challenges of community-based rural drinking water supplies: an analysis of water and sanitation committees 
in Ghana. International Food Policy Research Institute (IFPRI) discussion paper 01026. 2010.

7. RAJIV P., HASNA A., KAMARAJ M., RAJESHWARI S., SANKAR A. Physicochemical and Microbial Analysis of Different River Waters in Western Tamil Nadu, India. International Journal of Environmental Sciences. 1, 2, 2012.

8. AGBAIRE P.O., OBI C.G. Seasonal variation of some physico-chemical properties of River Ethiope water in Abraka, Nigeria. Journal of Applied Sciences and Environmental Management 13, 55, 2009.

9. NAJAFPOUR ALKARI A.F.M., KADIR M.O.A., NAJAFPOUR G.H.D. Evaluation of spatial and Temporal variation in river water quality. International Journal of Environmental Research. 2, 349, 2008.

10. WHO World Health Organization. Guidelines for drinkingwater quality, fourth edition. Recommendations, vol. 1. WHO Press Geneva Switzerland 2011. Available: http:// www.who.int/water_sanitation_health/publications/2011/ dwq_guidelines/en/. Accessed: 7 November, 2017.

11. WHO. United Nations; The Right to Water. Fact Sheet No. 35; WHO: Geneva, Switzerland, 1, 2010.

12. RAJESHWARI C.V., SARASWATHI B. Assessment of water quality of Rivers Tungabhadra and Hundri, India. Pollution Research. 28, 499, 2009.

13. KOLAREVIĆ S., KNEŽEVIĆ-VUKČEVIĆ J., PAUNOVIĆ M., GAČIĆ Z., VUKOVIĆ GAČIĆ B. Assessment of the microbiological quality of the River Tisa in Serbia. Water Research and Management. 1, 57, 2011.

14. ANNALAKSHMI G., AMSATH A. Nutrient status of Arasalarriver, a tributary of cauvery river at Tanjore district of Tamilnadu, India. International Journal of Plant, Animal and Environmental Sciences. 2, 214, 2012.

15. SCHAEFER M. Water technologies and the environment: Ramping up by scaling down. Technology in Society. 30, 415, 2008.

16. UNICEF/WHO. Diarrhoea: Why Children Are Still Dying and What Can Be Done. 2009. Available:http://www. unicef.org/health/files/Final_Diarrhoea_Report_October final. pdf. Accessed: 26 June 2016.

17. WHO/UNICEF Joint Monitoring Programme for Water Supply and Sanitation 2010 Meeting the MDG drinkingwater and sanitation target: A mid-term assessment of progress. Geneva, New York: WHO/UNICEF.

18. AJAI A.I., JACOB J.O., NDAMITSO M.M., ABDULGAFAR J. Physicochemical Characteristics and Trace Metal Levels of Locally Dug Wells in Tunga Area of Minna, Nigeria. Journal of Applied Sciences and Environmental Management. 15, 247, 2011.

19. NATIONAL BUREAU OF STATISTICS. 2006. Available: www.geo.com/cntry/nigreria, Accessed: 28 February 2014.

20. ADEDIJI A., AJIBADE L.T. The change detection of major dams in Osun State,Nigeria using remote sensing (RS) and GIS techniques. Journal of Geography and Regional Planning. 1, 110, 2008.

21. APHA (American Public Health Association). Standard Methods for the Examinations of Water and Wastewater, $22^{\text {nd }}$ ed. of American Public Health Association, Washington, DC. 2012

22. KHALID K.A., KADHUM H.A., SEBA H.A. Bacteriological and Physicochemical Studies on Tigris River Near the Water Purification Stations within Baghdad Province. Journal of Environmental and Public Health. doi:10.1155/2012/695253. 2012.
23. USHARANI K., UMARANI K., AYYASAMY P.M., SHANTHI K., LAKSHMANAPERUMALSAMY P. Physicochemical and bacteriological characteristics of Noyyal River and groundwater Quality of Perur, India. Journal of Applied Sciences and Environmental Management, 14, 29, 2010.

24. AREMU M.O., OLAOFE O., IKOKOH P.P., YAKUBU M.M. Physicochemical characteristics of stream, well and borehole water sources in Eggon, Nasarawa State, Nigeria. Journal of Chemical Society of Nigeria. 36, 131, 2011.

25. EDIMEH P.O., ENEJI I.S., OKETUNDE O.F., SHA'ATO R. Physico-chemical parameters and some Heavy metals content of Rivers Inachalo and Niger in Idah, Kogi State. Journal of Chemical Society of Nigeria. 36, 95, 2011.

26. SIBANDA T., CHIGOR V.N., KOBA S., OBI C.L., OKOH A.I. Characterisation of the physicochemical qualities of a typical rural-based river: ecological and public health implications. International Journal of Environmental Science and Technology. 11, 1771, 2014.

27. PATIL P.N, SAWANT D.V, DESHMUKH R.N. Physicochemical parameters for testing of water - A Review. International Journal of Environmental Sciences. 3, 1194, 2012.

28. EADY B.R., RIVERS-MOORE N.A., HILL T.R. Relationship between water temperature predictability and aquatic macroinvertebrate assemblages in two South African streams. African Journal of Aquatic Science. 38, 163,2013

29. VERMA P.U., CHANDAWAT D.K., GUPTA U., SOLANKI H.A. Water quality analysis of an organically polluted lake by investigating different physical and chemical parameters. International Journal of Research in Chemistry and Environment. 2, 105, 2012.

30. EDOKPAYI J.N., ODIYO J.O., OLASOJI S.O. Assessment of heavy metal contamination of Dzindi River, in Limpopo Province, South Africa. International Journal of Natural Sciences Research. 2, 185, 2014.

31. ALMEIDA C., GONZALEZ S.O., MALlEA M., GONZALEZ P. A recreational water quality index using chemical, physical and microbiological parameters. Environmental Science and Pollution Research. 19, 3400, 2012.

32. OSODE N.A., OKOH I.A. Impact of discharged wastewater final effluent on the physicochemical qualities of a receiving watershed in a suburban community of the Eastern Cape Province. Clean. 37, 938, 2009.

33. EPA. Technical Support Document for the Endangerment and Cause or Contributes Findings for Greenhouse Gases Under Section 202(a) of the Clean Air Act. U.S. Environmental Protection Agency. 2009.

34. GUPTA N., PANDEY P., HUSSAIN J. Effect of Physicochemical and biological parameters on the quality of river water of Narmada, Madhya Pradesh, India. Water Science. 31, 11, 2017.

35. IGBINOSA E.O., OKOH I.A. Impact of discharge wastewater effluents on the physico-chemical qualities of a receiving watershed in a typical rural community. International Journal of Environmental Science and Technology. 6, 175, 2009.

36. SHABALALA A.N., COMBRINCK L., MCCRINDLE R. Effect of farming activities on seasonal variation of water quality of Bonsma Dam, KwaZulu-Natal. South African Journal of Science. 109, 1, 2013.

37. MURHEKAR G.H. Determination of Physico-Chemical parameters of Surface Water Samples in and around Akot 
City. International Journal of Research in Chemistry and Environment, 1, 183, 2011.

38. SUTHAR S., SHARMA J., CHABUKDHARA M., NEMA A.K. Water quality assessment of river Hindon at Ghaziabad, India: impact of industrial and urban wastewater. Environmental Monitoring and Assessment. 165, 103, 2010.

39. NYAMANGRA J., JEKE N., RURINDA J. Long term nitrate and phosphate loading river water in the Upper Manyane catchment, Zimbabwe. Water SA. 39, 637, 2013.

40. EPA. Effect of treatment on nutrient availability. 2007. Available at: http://www.epa. gov/ogwdw/disinfection/tcr/ pdfs/issuepaper_tcr_treatment-nutrients.pdf.Accessed: 25 June 2014.

41. ODJADJARE E.E.O., OKOH A.I. Physicochemical quality of an urban municipal wastewater effluent and its impact on the receiving environment. Environmental Monitoring and Assessment. 170, 394, 2010.

42. SUTHAR M.B., MESARIYA A.R., RAWAT N.M. Study on drinking water quality from some areas of Ahmedabad city of Gujarat. Electronic Journal of Environmental Sciences. 1, 23, 2008.

43. ROBERT J.W. Water Clinic Nitrate, Sulphates. 2006. Available: http://www.thewater cliniccom/nitratesulphate. htm. Accessed: 15 June 2015.

44. FATOKI S.O., GOGWANA P., OGUNFOWOKAN A.O. Pollution assessment in the Keiskamma River an in the impoundment downstream. Water SA. 29, 183, 2003.

45. ABDUL A., RAZAK A.B., ASIEDU R.E.M. Assessment of water quality of the Oti River in Ghana. West African Journal of Applied Ecology. 15, 1, 2009.

46. DUBROVSKY N., HAMILTON P. Nutrients in the nation's streams and groundwater: national findings and implications. Reston, VA, United States Geological Survey (Fact Sheet 2010-3078; http://pubs.usgs.gov/fs/2010/3078/). 2010.

47. RAMACHANDRA T.V., SUBASH CHANDRAN M.D., JOSHI N.V., RAJINIKANTH R. KUMAR R. Sahyadri Conservation Series 4, Environmental Information System (ENVIS) Technical Report: 21, India. 2012.

48. JULIE S.R., VASANTHA S. Physicochemical analysis of bore well water samples of Anaiyur area in Madurai district, Tamilnadu, India. Journal of Current Science. 15, 403, 2010

49. NAUBI I., ZARDARI N.H., SHINAZI S.M., IBRAHIM N.F.B., BALOO M.L. Effectiveness of Water Quality Index for Monitoring Malaysian Water Quality Index. Polish Journal of Environmental Studies. 25, 231, 2016.

50. RABEE A.M., ABDUL-KAREEM B.A., AL-DHAMIN A. Ecological Parameters in Tigris River Water at Baghdad Region, Iraq. Journal of Water Resource and Protection. 3, 262, 2011.

51. ELMORE L.R., NULL S.E., MOUZON N.R. Effects of environmental water transfers on stream temperatures. River Research and Applications. 32, 1415, 2015.

52. FICKLIN D.L., STEWART I.T., MAURER E.P. Effects of climate change on stream temperature, dissolved oxygen, and sediment concentration in the Sierra Nevada in California Water Resources Research. 49, 2765, 2013.

53. BHUTIANI R., KHANNA D.R. Ecological study of river Suswa: modeling DO and BOD. Environmental Monitoring and Assessment. 125, 183, 2007.

54. KANNEL P.R., LEE S., LEE Y., KANEL S.R. KHAN S.P. Application of water quality indices and dissolved oxygen as indicators for river classification and urban impact assessment. Environmental Monitoring and Assessment. 132, 93, 2007.

55. KATARIA H.C., SINGH A., PANDEY S. Studies on water quality of Dahod Dam, India. Pollution Research. 25, 553, 2006.

56. AYEDUN H., TAIWO A.M., UMAR B.F., OSENI O.A., ODERINDE A.A Assessment of groundwater contamination by toxic metals in Ifo, Southwestern Nigeria. Indian Journal of Science and Technology. 4, 820, 2011.

57. WHO. Burden of disease and cost effectiveness estimates. World Health Organization, Geneva. 2006.

58. ADEKUNLE I.M., ADETUNJI M.T., GBADEBO, A.M., BANJOKO O.B. Assessment of groundwater quality in a typical rural settlement in Southwest Nigeria. International Journal Environmental Research and Public Health. 4, 307, 2007.

59. AMADI B.A., CHIKEZIE P.C., OKEOMA H.C. Physicochemical characteristics of Nworie River and its effect on liver function of rats. Journal of Nigerian Environmental Society. 3, 183, 2006.

60. USGS (United States Geological Survey). National Field Manual for the Collection of Water Quality Data, Techniques of Water Resources Investigations, Book 9, Handbooks for Water Resources Investigations, 1539. 2015.

61. ANGADI S.B., SHIDDAMALIAYYA N., PATIL P.C. Limnological study of papnash pond, Bidar (Karnataka). Journal of Environmental Biology. 26, 213, 2005.

62. AKUBUGWO E.I., OFOEGBU C.I., UKWUOMA C.U. Physicochemical studies on Uburu Salt Lake Ebonyi State Nigeria. Pakistan Journal of Biological Sciences. 10, 3170, 2007.

63. SINGH J., AGRAWAL D.K., PANWER S. Seasonal variations in different physicochemical characteristics of Yamuna river water quality in proposed Lakhwar hydropower project influenced area. International Journal of Applied Environmental Sciences. 3, 107, 2008.

64. SHINDE S.E., PATHAN T.S., RAUT K.S., SONAWAN D.L. Studies on the physico-chemical parameters and correlation coefficient of Harsool savani Dam, District Aurangabad, India. Middle East Journal of Scientific Research. 8, 544, 2011.

65. KEMKER C. "pH of Water." Fundamentals of Environmental Measurements. Fondriest Environmental, Inc. 2013. Available: http://www.fondriest.com/ environmental-measurements/parameters/water quality/ ph/. Accessed: 10 September 2016.

66. IBRAHIM A.E.M., OSMAN B.O., MOHAMED-ALI M.H. Assessment of Physicochemical parameters of surface water sources in Kusti Town - Sudan. European Journal of Pharmaceutical and Medical Research. 2, 44, 2015.

67. IBRAHIM B.U., AUTA J., BALOGUN J.K. An Assessment of the Physico-chemical Parameters of Kontagora Reservoir, Niger State, Nigeria. Journal of Pure and Applied Sciences. 2, 64, 2009.

68. CHOUDHORY R., RAWRANI P., VISHWAKARMA M. Comparative study of Drinking Water Quality Parameters of three Manmade Reservoirs i.e. Kolar, Kaliasote and Kerwa Dam. Current World Environment. 6, 145, 2011.

69. KILMAREN E. Symptoms from Drinking Coliform Bacteria in Water. 2011. Available: http://www.livestrong. com/article/123179-symptoms-drinking-coliform-bacteriawater. Accessed: 17 November 2014. 
70. EMMANUEL E., PIERRE M.G., PERRODIN Y. Groundwater contamination by microbiological and chemical substances released from hospital wastewater and health risk assessment for drinking water consumers, Environment International. 35, 718, 2009.

71. AZALEA A.M., KATHRINE C.G., WILLIAM A.M. Faecal coliform accumulation within a river subject to seasonally-disinfected wastewater discharges. Water Research, 44, 4776, 2010.

72. ZAMXAKA M., PIRONCHEVA G., MUYIMA N.Y.O. Microbiological and physicochemical assessment of the quality of domestic water sources in selected rural communities of the Eastern Cape Province, South Africa. Water SA. 30, 333, 2004.

73. MANASRAH R., RAHEED M., BADRANPRIMARY M.I. Relationships between water temperature, nutrients and dissolved oxygen in the northern Gulf of Aqaba, Red Sea. Oceanologia. 48, 237, 2006.

74. ACHUTHAN N.G., ABDULLAH I.M., MAHAMOUD M.F. Physio-chemical parameters and correlation coefficients of ground waters of North-East Libya. Pollution Research. 24, 1, 2005. 